\title{
Correction to: Role of identified bacterial consortium in treatment of Quhafa wastewater treatment plant influent in Fayuom, Egypt
}

\author{
Salma Ibrahim • Mohamed Azab El-Liethy • Khalid Z. \\ Elwakeel • Mohammed Abd El-Gabbar Hasan • Ali \\ Mahmoud Al Zanaty • Mohamed Mohamed Kamel
}

Published online: 13 April 2020

(C) Springer Nature Switzerland AG 2020

\section{Correction to: Environ Monit Assess \\ https://doi.org/10.1007//10661-020-8105-9}

The online version of the original article can be found at https://doi.org/10.1007/s10661-020-8105-9

\author{
S. Ibrahim \\ Water and Wastewater Company, El-Fayoum Governorate, \\ Fayuom, Egypt \\ M. A. El-Liethy • M. M. Kamel \\ Environmental Microbiology Lab., Water Pollution Research \\ Department, National Research Centre, Dokki, Giza 12622, Egypt
}

M. A. El-Liethy

e-mail: mohamedazabr@yahoo.com

M. A. El-Liethy $\cdot$ K. Z. Elwakeel

College of Science, Department of Chemistry, University of

Jeddah, Jeddah, Saudi Arabia

\section{K. Z. Elwakeel $(\bowtie)$}

Environmental Science Department, Faculty of Science, Port Said University, Port Said, Egypt

e-mail: Khalid_elwakeel@yahoo.com

e-mail: Khalid_elwakeel@sci.psu.edu.eg

M. A. E.-G. Hasan · A. M. Al Zanaty

Biochemistry Department, Faculty of Science, Beni-Suef

University, Beni Suef, Beni-Suef Governorate, Egypt
The original version of this article unfortunately contained an error.

The city "Cairo" that was included in the affiliation section should be changed to "Fayuom." The corrected affiliation 1 is shown below.

The title "Results and Discussion" before the title "Identification of the Investigated Bacterial Consortium" was missing in the published paper. The corrected paragraph is shown below.

\section{Results and Discussion}

Identification of the investigated bacterial consortium

The bacterial consortium of BiOWiSH Aqua was identified using Biolog GEN III. The most probable identified bacterial strains were Pediococcus acidilactici, Pediococcus pentosaceus, Lactobacillus plantarum, and Bacillus subtilis. All of these identified bacterial strains are nonpathogenic bacteria. Pediococcus acidilactici, Pediococcus pentosaceus, and Lactobacillus plantarum are lactic acid bacteria, are Gram-positive bacteria, and have the ability to exert antagonism against other microorganisms, including enteric pathogens 
(Daeschel and Klaenhaemmer 1985; Pritchard and Coolbear 1993; María et al. 2010). Bacillus subtilis is a Gram-positive bacterium, and it is one of the bacterial champions in secreted enzyme production and is used on an industrial scale by biotechnology companies (Euzéby 2008).
The online version of the original article can be found at https://doi.org/10.1007/s10661-020-8105-9.

Publisher's note Springer Nature remains neutral with regard to jurisdictional claims in published maps and institutional affiliations. 